\title{
Transtracheal endoscopic-assisted resection of a rare inflammatory myofibroblastic tumour in adult trachea: a case report
}

\author{
Resezione transtracheale endoscopio-assistita di un raro tumore miofibroblastico \\ infiammatorio della trachea di un paziente adulto: case report
}

\author{
S. REDDY ${ }^{1}$, R. SWAMY ${ }^{1}$, D.V. KUMAR IRUGU², K.V.V. RAMJI ${ }^{1}$ \\ ${ }^{1}$ Department of Otorhinolaryngology \& Head and Neck Surgery, Govt ENT Hospital, Osmania Medical College, \\ Hyderabad, India; ${ }^{2}$ Department of Otorhinolaryngology \& Head and Neck Surgery, All India Institute of Medical \\ Sciences, New Delhi, India
}

\section{SUMMARY}

Inflammatory myofibroblastic tumours (IMTs) are rare and clinically benign in childhood, and malignant in adults. The aetiology of IMTs is not clear, and recent studies report it as true neoplasm rather than a reactive or inflammatory lesion. IMTs can involve any part of the body, but are usually common in lungs. These are rarely seen in adults and tracheal involvement is also rare in both adults and children. We describe an 18-year-old woman who presented with respiratory difficulty to the emergency department. On clinical examination, the patient had complete absence of breath sounds on the right side of the chest. CT of the chest and virtual bronchoscopy revealed a polypoidal soft tissue mass lesion involving the carina with occlusion of right main bronchus. Endoscopic-assisted resection was performed under general anaesthesia and the final pathological diagnosis was tracheal IMT.

KEY WORDS: Strider • Inflammatory myofibroblastic tumour • Trachea $\bullet$ Bronchus $\bullet$ Spindle cell proliferation

\section{RIASSUNTO}

I tumori miofibroblastici infiammatori sono rari in età pediatrica, età nella quale sono clinicamente benigni; sono invece maligni in età adulta. L'eziologia non è chiara, recenti studi affermano che essi siano delle vere neoplasie piuttosto che delle lesioni reattive o infiammatorie. I tumori miofibroblastici infiammatori sono raramente riscontrati negli adulti e il coinvolgimento tracheale è raro sia nei bambini sia negli adulti. Noi descriviamo il caso di una paziente di sesso femminile di diciotto anni, che si è presentata al pronto soccorso per difficoltà respiratoria. All'esame clinico della paziente si evidenziava assenza dei suoni polmonari a destra, pertanto si eseguiva TC del torace e la broncoscopia virtuale rivelava una lesione polipoide soffice che coinvolgeva la carena occludendo completamente il bronco principale di destra. La resezione endoscopio-assistita è stata eseguita in anestesia generale e all'esame istopatologico definitivo la diagnosi è stata di tumore miofibroblastico infiammatorio.

PAROLE CHIAVE: Stridor $\bullet$ Tumore miofibroblastico infiammatorio $\bullet$ Trachea $\bullet$ Bronco $\bullet$ Proliferazione a cellule fusate

Acta Otorhinolaryngol Ital 2018;38:170-173

\section{Introduction}

Inflammatory myofibroblastic tumours (IMT) are rare tumours, commonly seen in children less than 16 years of age and with frequency of $0.04-0.07 \%$ of all respiratory tract tumours ${ }^{1-6}$. The World Health Organization defines it as a lesion consisting of myofibroblastic spindle cells accompanied by an inflammatory infiltrate of plasma cells, lymphocytes and eosinophils ${ }^{1256}$. The aetiology of the disease is still not clear ${ }^{2}$. Tracheal IMTs are rarely reported in adults who are malignant and benign in children ${ }^{12}$. In 1939 , the first case of IMT was reported in the lungs ${ }^{4}$. A wide variety of names has been applied to IMTs which are mentioned in Table $I^{1-46-8}$. Because of its rarity, we report the case of 18-year-old woman with an IMT in the trachea.

\section{Case report}

An 18-year-old woman reported to the emergency depart- 
Table I. Other names of inflammatory myofibroblastic tumour.

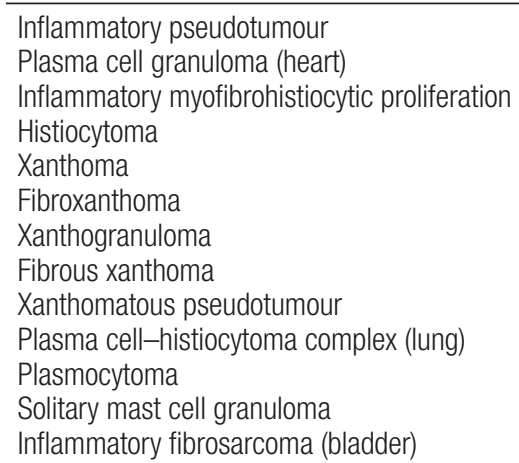

ment with difficulty in breathing since four months with insidious onset. The patient had significant loss of weight and there was no history of wheezes, chest pain, haemoptysis, or fever. On examination, the patient was thin with stable vitals and complete absence of breath sounds on right side of chest. Patient was subjected to CT of chest and neck and virtual bronchoscopy revealed a polypoidal soft tissue mass lesion involving the carina with occlusion of right main bronchus causing collapse of the right lung with crowding of right sided ribs and ipsilateral mediastinal shift (Fig. 1). The senior author (SA) performed rigid bronchoscopic examination under general anaesthesia to confirm the above findings and simultaneously the woman was admitted for surgery (Fig. 2 a).

Under jet ventilation general anaesthesia the supine position, anterior tracheotomy was performed and the trachea was transposed anteriorly by using 1-0 prolene suture. Through the tracheotomy a $4 \mathrm{~mm} 0^{\circ}$ rigid endoscope was passed and the tumour mass removed with insulated instruments (Fig. 2 b). The tracheotomy opening was closed with 1-0 vicryl suture and the incision was closed in lay-
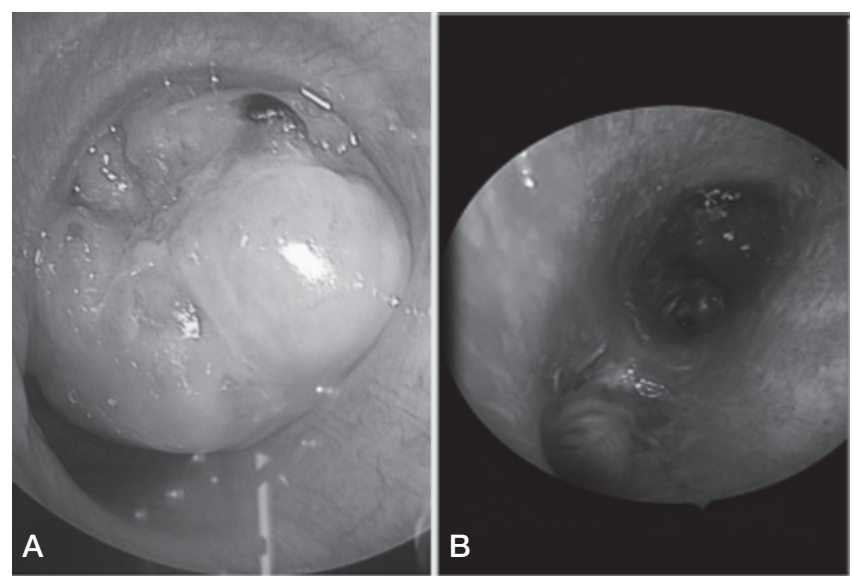

Fig. 2. (A) Endoscopic-assisted bronchoscopy showing the tracheal tumour occluding the right main bronchus. (B) After tumour removal.

ers. The mass sent for histopathological examination, which was suggestive of inflammatory myofibroblastic tumour of the trachea (Fig. 4).

The patients was given tapering doses of corticosteroid postoperatively for 10 days and to date we are following the case without recurrence.

\section{Discussion}

IMTs are rare tumours, commonly seen in children less than 16 years of age and with a frequency of $0.04-0.07 \%$ among all the respiratory tract tumours ${ }^{1-6}$. The World Health Organization defines it as a lesion consisting of myofibroblastic spindle cells accompanied by an inflammatory infiltrate of plasma cells, lymphocytes and eosinophils ${ }^{1256}$. Adult IMTs occurring in the trachea are malignant ${ }^{12}$.

A variety of names are applied for IMTs as mentioned in
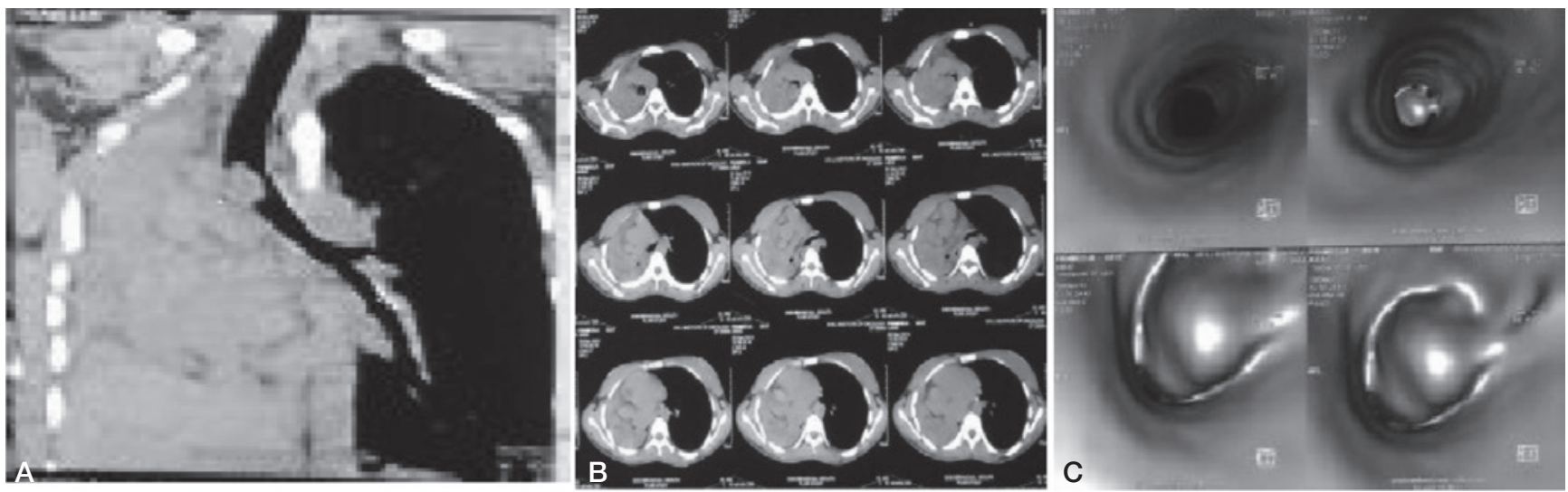

Fig. 1. (A) and (B) CT of chest images. (C) Virtual bronchoscopy image showing a polypoidal mass obscuring the right main bronchus. 


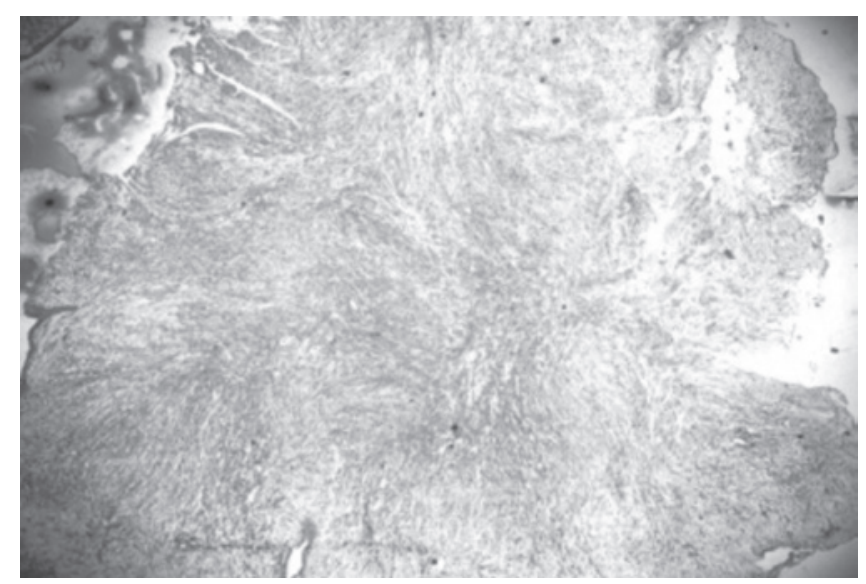

Fig. 3. Histopathological examination suggested inflammatory myofibroblastic tumour.

Table $\mathrm{I}^{1-46-8}$. The aetiology of the disease is still not clear, but is probably the cause is an inflammatory reaction secondary to trauma, immune reaction, or infection ${ }^{246}$. IMTs are most commonly seen in lungs, but can develop in any part of the body (Table II) ${ }^{1-68-11}$. The symptoms of IMTs are usually nonspecific and depend on its location. Most respiratory tract IMTs are presented with dyspnoea, strider, chronic cough, haemoptysis and pleuritic chest pain.

Radiological evaluation with PA and left lateral chest radiograms, CT imaging and endoscopy (bronchoscopic) examination are the diagnostic methods for evaluation. The radiological evaluation gives the information about the tracheal lumen ${ }^{138}$. IMTs are in the differential diagnosis with other tracheal tumours and tissue biopsy is needed for definitive diagnosis. Immunohistochemical study of IMTs is positive for vimentin, muscle-specific

Table II. Common sites for inflammatory myofibroblastic tumour.

\begin{tabular}{ll}
\hline Airway & Chest \\
Lung & Oesophagus \\
Nasal cavity & Heart \\
Nasopharynx & Breast \\
Larynx & Gl \\
Trachea & Stomach \\
Head \& Neck & Liver \\
Orbit & Spleen \\
Oesophagus & Pancreas \\
Thyroid & Kidney \\
Tonsil & Adrenal gland \\
Maxillary sinus & Retroperitoneum \\
Fourth ventricle & Diaphragm \\
Spinal cord meninges & Mesentery \\
Central nervous system & Genitourinary system \\
& Testis \\
& Bladder \\
\hline
\end{tabular}

Table III. Basic histologic patterns of inflammatory myofibroblastic tumour (Coffin et al.)

1. Myxoid/ Vascular pattern: Fasciitis-like appearance and loosely arranged plump spindle cells in an oedematous myxoid stroma with prominent vasculature. It has inflammatory infiltrate of more neutrophils, eosinophils and few plasma cells than the other two patterns.

2. Compact spindle cell pattern: Cellular proliferation of spindle cells with fascicular or storiform architecture in a collagenous stroma and typically show numerous plasma cells and lymphocytes mixed with spindle cells, but discrete lymphoid follicle and aggregates of plasma cells are common.

3. Fibromatosis-like pattern: Relatively hypocellular with elongated spindle cells in a densely collagenous background containing scattered lymphocytes, plasma cells and eosinophils.

actin, SMA and cytokeratin, which are characteristic for myofibroblats ${ }^{13413}$.

Simple surgical excision of the tumour with a normal rim of tissue is the treatment of choice. However, endoscopic-assisted resection may be a choice of approach to remove the endoluminal tumours ${ }^{1-57111214}$. CO2 laser or electrocautery is also documented in the literature. Radiotherapy and chemotherapy are reserved for cases of recurrence ${ }^{1-4111214}$.

Histologically, IMTs have variable cellular spindle cell proliferation in a myxoid to collagenous stroma with a prominent inflammatory infiltrate of plasma cells and lymphocytes with some eosinophils and neutrophils. Coffin et al. described three histologic patterns which are tabulated below (Table III) ${ }^{9}$. Salvatore et al. described three types depending on the predominant cell types ${ }^{7}$ :

1. Organising pneumonia type with predominant fibroblast-like spindle cells;

2. Fibrous histiocytoma type;

3. Lymphoplasmacytic typeDeath can occur by local recurrence and in cases with infiltration to mediastinal organs or rarely due to distant metastasis ${ }^{8}$.

\section{Conclusions}

IMT of the trachea are rare and pose a diagnostic dilemma. Most cases present with nonspecific symptoms. Radiological and endoscopic assessment are useful, but tissue biopsy is needed for definitive diagnosis. Simple surgical resection is the treatment of choice; RT and CT are reserved for unresectable cases. Death can occur in local recurrence and infiltration to mediastinal organs, and rarely to distant metastasis. The prognosis of patients who undergo radical resection is excellent. 


\section{Acknowledgments}

We thank Dr. S. Ramakrishna, superintendent, Govt ENT Hospital, Koti, Hyderabad Dr. Nirmala, RMO Govt ENT Hospital, Koti, Hyderabad for allowing us to use hospital data.

\section{References}

1 Ozgül MA, Toru Ü, Acat M, et al. A rare tumor of trachea: Inflammatory myofibroblastic tumor diagnosis and endoscopic treatment. Respir Med Case Rep 2014;13:57-60.

2 Oztuna F, Pehlivanlar M, Abul Y, et al. Adult inflammatory myofibroblastic tumor of the trachea: case report and literature review. Respir Care 2013;58:e72-6.

3 Boloursaz MR, Khalilzadeh S, Dezfoli AA, et al. Inflammatory myofibroblastic tumor of the trachea. Pediatr Surg Int 2011;27:895-7.

4 Zhang T, Yuan Y, Ren C, et al. Recurrent inflammatory myofibroblastic tumor of the inguinal region: a case report and review of the literature. Oncol Lett 2015;10:675-80.

5 Laursen BB, Pedersen U, Kjærgaard T. Inflammatory myofibroblastic tumour of the trachea in a child with asthmatic symptoms. Ann Otolaryngol Rhinol 2015;2:1053-4

6 Pecoraro Y, Diso D, Anile M, et al. Primary inflammatory myofibroblastic tumor of the trachea. Respirol Case Rep 2014;2:147-9.
7 Privitera S, Hwang DM, Darling GE. Inflammatory myofibroblastic tumor of the left main stem bronchus. J Thorac Oncol 2006;1:726-8.

8 Khodadad K, Hashemi N, Karimi S, et al. Inflammatory myofibroblastic tumor of the lung: case series. Tanaffos 2009;8:68-74.

9 Gleason BC, Hornick JL. Inflammatory myofibroblastic tumours: where are we now? J Clin Pathol 2008;61:428-37.

10 Jacob SV, Reith JD, Kojima AY, et al. An unusual case of systemic inflammatory myofibroblastic tumor with successful treatment with ALK-inhibitor. Case Rep Pathol 2014;2014:470340.

11 Katara AN, Chandiramani VA, Dastur FD, et al. Inflammatory pseudotumor of ascending colon presenting as PUO: a case report. Indian J Surg 2004;66:234-6.

12 Maturu VN, Bal A, Singh N. Inflammatory myofibroblastic tumor of the lung in pregnancy mimicking carcinoid tumor. Lung India 2016;33:82-4.

13 Kim HJ, Jong IN, Lee JS, et al. Inflammatory myofibroblastic tumor of the thyroid gland: a brief case report. Korean $\mathrm{J}$ Pathol 2014;48:319-22.

14 Johnson K, Notrica DM, Carpentieri D, et al. Successful treatment of recurrent pediatric inflammatory myofibroblastic tumor in a single patient with a novel chemotherapeutic regimen containing celecoxib. J Pediatr Hematol Oncol 2013;35:414-6.

Address for correspondence: David Victor Kumar Irugu, Department of Otorhinolaryngology \& Head and Neck Surgery, All India Institute of Medical Sciences, Anasarinagar, New Delhi110029, India. E-mail: davvkumar.14@gmail.com 